\title{
THE USE OF DEMONSTRATION METHOD IN MAGNETIC MEDIA TO IMPROVE STUDENTS ACTIVITY AT THE FIFTH GRADE STUDENT IN SD NEGERI 08 PINANG SEBATANG TIMUR IN KECAMATAN TUALANG KABUPATEN SIAK
}

\author{
MAHYAR
}

Volume 2 Nomor 1

JIPS ISSN: 2579-5449

\begin{abstract}
Students are accustomed to memorizing facts, principles, formulas, laws and problems given by the teacher, thus understanding the concept tends to be low. Description of daily test value obtained from 25 students that is, the average value of 54.80 with the percentage of the value reached $48 \%$ only KKM. From the description above we need the new treatments to improve student achievement and learning activities.
\end{abstract}

ABSTRACT

In order to improve learning outcomes, it can be improved through demonstration methods and media in the form of real objects that exist around, so that students no longer have difficulty in understanding the material. Based on the above, then that becomes the problem in this study can be formulated as follows: 1) Do the media magnets, magnetic objects, cable and battery can improve student achievement at the fifth grade student in SD Negeri 08 Pinang sebatang Timur Kecamatan Tualang Kabupaten Siak about making magnets ? 2) Does the demonstration method can improve students' learning activities at the fifth grade students in SD Negeri 08 Pinang sebatang Timur Kecamatan
Tualang Kabupaten Siak about making a magnet?

The subject in this classroom action research is a fifth grade students of SDN 08 Pinang sebatang Timur Kecamatan Tualang Kabupaten Siak at the second semester in the academic year 2014/2015 the number of students 25 people, consisting of 9 men and 16 women with different levels of ability to understand the lesson. Classroom action research was carried out in SDN 08 Pinang sebatang Timur Kecamatan Tualang Kabupaten Siak. Researchers take this location or place with the consideration of working at the school concerned, making it easier in search of data, the opportunity of time wide and subject of the research that is in accordance with the profession researchers.

Based on the results above we concluded that the application of methods of demonstration can improve student learning outcomes in science subjects in SDN 08 Pinang sebatang Timur Kecamatan Tualang Kabupaten Siak in second semester of 2014/2015.

\section{METODE DEMONSTRASI MEMBUAT MEDIA MAGNET DAPAT \\ MENINGKATKAN AKTIVITAS BELAJAR SISWA V SD NEGERI 08 PINANG SEBATANG TIMUR DI KECAMATAN TUALANG KABUPATEN SIAK}




\section{ABSTRAK}

Siswa terbiasa dengan menghafal fakta-fakta, prinsip, rumus, hukum-hukum dan problemproblem yang diberikan oleh guru, dengan demikian pemahaman konsep cenderung rendah. Gambaran nilai ulangan harian yang diperoleh dari 25 siswa yaitu, rata rata nilai 54,80 dengan prosentase nilai mencapai KKM hanya $48 \%$. Dari gambaran tersebut perlu adanya perlakuan baru guna peningkatan prestasi dan aktivitas belajar siswa.

Agar dapat meningkatkan hasil pembelajaran maka dapat dilakukan perbaikan melalui metode demonstrasi dan media berupa benda nyata yang ada disekitar, sehingga siswa tidak lagi mengalami kesulitan dalam memahami materi. Berdasarkan latar belakang diatas, maka yang menjadi permasalahan dalam penelitian ini dapat dirumuskan sebagai berikut : 1) Apakah dengan media magnet, benda magnetik, kabel dan betere dapat meningkatkan prestasi belajar siswa kelas V SD Negeri 08 Pinang sebatang Timur Kecamatan Tualang Kabupaten Siak tentang membuat magnet ? 2) Apakah dengan metode demonstrasi dapat meningkatkan aktivitas belajar siswa V SD Negeri 08 Pinang Sebatang Timur di Kecamatan Tualang Kabupaten Siak tentang membuat magnet?

Sebagai Sabjek dalam Penelitian tindakan kelas ini adalah siswa kelas V SDN 08 Pinang Sebatang Timur semester genap Tahun Pelajaran 2014/2015 dengan jumlah siswa 25 orang,terdiri dari 9 orang laki-laki dan 16 orang perempuan dengan tingkat kemampuan memahami pelajaran berbeda-beda.Penelitian tindakan kelas ini dilaksanakan di SD Negeri 08 Pinang Sebatang Timur Kecamatan Tualang Kabupaten Siak. Peneliti mengambil lokasi atau tempat ini dengan pertimbangan bekerja pada sekolah yang bersangkutan,sehingga memudahkan dalam mencari data,peluang waktu yang luas dan sabjek penelitian yang sangat sesuai dengan profesi peneliti.

Berdasarkan hasil penelitian diperoleh kesimpulan bahwa penerapan metode demonstrasi dapat meningkatkan hasil belajar siswa pada mata pelajaran IPA kelas V SD Negeri 08 Pinang Sebatang Timur semester genap tahun 2014/2015.

\section{Kata Kunci: media magnet dapat meningkatkan aktivitas belajar siswa}

\section{PENDAHULUAN}

Pengembangan kemampuan siswa dalam bidang sains (IPA) merupakan salah satu kunci keberhasilan peningkatan kemampuan dalam menyesuaikan diri dengan perubahan jaman dan memasuki dunia teknologi, termasuk teknologi informasi. Pendidikan di masa sekarang ini seyogyanya mampu membekali generasi muda dengan menemukan konsep-konsep sains dengan matang, agar masalah-masalah yang akan timbul dimasa datang dapat diantisipasi.

Sains merupakan cara mencari tahu tentang alam sekitar secara sistematis. Belajar sains tidak cukup hanya mengahafal materinya saja tetapi juga harus dapat memahami konsepkonsep didalamnya. Hal ini dapat tercapai jika pembelajaran tersebut bermakna. Berdasarkan KTSP 2006 tujuan pembelajaran sains meliputi : mengembangkan pemahaman tentang berbagai macam gejala alam, konsep dan prinsip sains yang bermanfaat dan dapat diterapkan dalam kehidupan sehari-hari, melakukan kerja ilmiah untuk membentuk sikap ilmiah, meningkatkan kesadaran untuk menghargai alam dan segala keteraturannya sebagai salah satu ciptaan Tuhan, meningkatkan pengetahuan, konsep dan keterampilan IPA sebagai dasar melanjutkan pendidikan ke jenjang yang lebih tinggi.

Sekolah Dasar merupakan tempat pembelajran untuk mendapatkan pengetahuanpengetahuan dasar tentang konsep maupun prinsip-prinsip, mengembangkan sikap kritis dan kreatif dimana kemampuan ini menjadi pijakan dalam pembelajaran selanjutnya. Keberhasilan pembelajaran di SD ini akan mendorong 
keberhasilan pembelajaran di tingkat yang lebih tinggi.

Guru bertugas mengoptimalkan kemampuan dasar siswa agar berkembang secara efektif. Seorang guru harus dapat menjadi fasilitator siswa, agar siswa tidak mengalami kesulitan dan kebosanan dalam kegiatan belajar mengajar.

Melihat hasil ulangan harian siswa pada pembelajaran IPA pada Standar Kompetensi Memahami hubungan antara gaya, gerak, dan energi serta fungsinya, Kompetensi Dasar Mendeskripsikan hubungan antara gaya, gerak, dan energi serta fungsinya, khususnya pada materi pembuatan magnet secara konduksi, gosokan dan elektromagnetik ditemukan prestasi dan aktivitas belajar siswa yang rendah. Alasan rendahnya prestasi dan aktivitas belajar siswa ini dimungkinkan karena pembelajaran yang digunakan guru masih konvensional yakni menggunakan metode ceramah. Kemungkinan lain adalah guru masih mengalami kesulitan dalam menyusun perangkat pembelajaran, LKS, alat peraga sederhana, dan penggunaan media lainnya. Dengan demikian akan sulit untuk mengembangkan keterampilan berpikir. Siswa terbiasa dengan menghafal fakta-fakta, prinsip, rumus, hukum-hukum dan problem-problem yang diberikan oleh guru, dengan demikian pemahaman konsep cenderung rendah.

Gambaran nilai ulangan harian yang diperoleh dari 25 siswa yaitu, rata rata nilai 54,80 dengan prosentase nilai mencapai KKM hanya $48 \%$. Dari gambaran tersebut perlu adanya perlakuan baru guna peningkatan prestasi dan aktivitas belajar siswa.
Agar dapat meningkatkan hasil pembelajaran maka dapat dilakukan perbaikan melalui metode demonstrasi dan media berupa benda nyata yang ada disekitar, sehingga siswa tidak lagi mengalami kesulitan dalam memahami materi.

Berdasarkan latar belakang diatas, maka yang menjadi permasalahan dalam penelitian ini dapat dirumuskan sebagai berikut : 1) Apakah dengan media magnet, benda magnetik, kabel dan betere dapat meningkatkan prestasi belajar siswa kelas V SD Negeri 08 Pinang sebatang Timur Kecamatan Tualang Kabupaten Siak tentang membuat magnet ? 2) Apakah dengan metode demonstrasi dapat meningkatkan aktivitas belajar siswa V SD Negeri 08 Pinang Sebatang Timur di Kecamatan Tualang Kabupaten Siak tentang membuat magnet ?

Dengan memperhatikan rumusan masalah di atas, maka hipotesis yang dapat penulis ajukan dalam rangka perbaikan pembelajaran ini adalah : Jika dalam pembelajaran IPA, khususnya materi Membuat Magnet guru menggunakan media dan metode yang tepat maka prestasi dan aktivitas siswa akan meningkat hasilnya.

Dari rumusan masalah diatas, dapat ditentukan adanya tujuan penelitian ini yaitu : 1) Untuk membuktikan bahwa hasil penggunaan media pembelajaran yang sesuai dapat meningkatkan prestasi belajar siswa di kelas $\mathrm{V}$ SDN 08 Pinang Sebatang Timur Kecamatan Tualang Kabupaten Siak. 2.Untuk mengetahui keefektifan penggunaan metode demonstrasi dalam meningkatkan aktivitas belajar siswa kelas V SDN 08 Pinang Sebatang Timur Kecamatan Tualang Kabupaten Siak.

\section{PELAKSANAAN PERBAIKAN PEMBELAJARAN PER SIKLUS}

Sebagai Sabjek dalam Penelitian tindakan kelas ini adalah siswa kelas V SDN 08 Pinang Sebatang Timur semester genap Tahun Pelajaran 2014/2015 dengan jumlah siswa 25 orang,terdiri dari 9 orang laki-laki dan 16 orang perempuan dengan tingkat kemampuan memahami pelajaran berbeda-beda.Penelitian tindakan kelas ini dilaksanakan di SD Negeri 08 Pinang Sebatang Timur Kecamatan Tualang Kabupaten Siak. Peneliti mengambil lokasi atau tempat ini dengan pertimbangan bekerja pada sekolah yang bersangkutan,sehingga memudahkan dalam mencari data,peluang waktu yang luas dan sabjek penelitian yang sangat sesuai dengan profesi peneliti.

Dengan beberapa pertimbangan dan alasan peneliti menggunakan waktu penelitian selama dua bulan yaitu mulai Januari sampai februari 2014.Penelitian dilakukan dalam dua siklus dilakukan dengan tiga kali pertemuan. Kegiatan perbaikan pembelajaran dilaksanakan selama satu bulan , yaitu dari bulan Januari sampai bulan Februari.

Menurut (Ropoport dalam Wiriatmadja, 2007) Penelitian tindakan kelas berguna membantu seseorang dalam mengatasi 
secara praktis persoalan yang dihadapi dalam situasi darurat dan membantu pencapaian tujuan dengan kerja sama dalam kerangka etika yang disepakati bersama.

Penelitian tindakan kelas ini dilakukan melalui dua siklus dengan masing masing siklus tiga kali pertemuan.Penelitian ini berbentuk penelitian tindakan kelas.

Model siklus PTK di atas menurut Arikunto (2006), yang dapat dijelaskan sebagai berikut : Perencanaan : Penelitian ini dilakukan oleh peneliti sebagai guru dan guru lain diminta sebagai pengamat. Peneliti melakukan perbaikan dengan menerapkan metode pembelajaran demontrasi. Perangkat pembelajaran berdasarkan langkah-langkah pembelajaran lansung terdiri dari 6 Rencana pelaksanaan pembelajaran, 6 LKS, dan 6 lembar pengamatan. Dan sangat diharapkan adanya perubahan setelah tindakan dengan model pembelajaran lansung serta adanya peningkatan hasil belajar (mencapai KKM 65). Pelaksanaan : Dalam pelaksanaan ini siswa belajar dan bekerja dengan menerapkan metode demontrasi yaitu pada pertemuan satu sampai tiga tiap-tiap siklusnya.Siswa belajar dengan mengikuti langkah pembelajaran demontrasi, menyelesaikan LKS yang diberikan guru,mengerjakan latihan lanjutan dan membuat kesimpulan.

Pengamatan : Pelaksanaan pembelajaran diamati setiap kali pembelajaran tentang aktivitas guru dan aktivitas siswa dalam metode demontrasi. Pengamat mengamati mulai dari kegiatan awal hingga kegiatan akhir pembelajaran. Mendeskripsikan dan menganalisis semua kegiatan yang disesuaikan dengan lembar pengamatan. Refleksi : Mengkaji secara menyeluruh tindakan yang telah dilakukan berdasarkan data yang terkumpul, dan kemudian dilakukan evaluasi untuk menyempurnakan tindakan. Jika terdapat masalah dari proses refleksi maka dilakukan pengkajian ulang melalui siklus berikutnya, Sehingga permasalahan dapat diselesaikan. Refleksi dilakukan peneliti bersama kolaborasinya yaitu pengamat dalam penelitian ini.

Penelitian ini menggunakan perangkat pembelajaran yang terdiri atas : silabus,rencana pelaksanaan pembelajaran (RPP),Lembar Kerja Siswa (LKS),Latihan terbimbing dan latihan lanjutan. Silabus, adalah salah satu kelangkapan administrasi guru yang seharusnya disusun oleh guru yang bersangkutan sebelum melaksanakan pembelajaran.silabus disusun sebagai acuan bagi guru dalam menyusun pelaksanaan pembelajaran (RPP),melaksanakan pembelajaran,dan melakukan penelitian dalam pembelajaran.silabus mencakup standar kompetensi,kompetensi dasar,materi pembelajaran,kegiatan pembelajaran,indikator dan penilaian,alokasi waktu,sumber/alat dan bahan. Rencana Pelaksanaan Pembelajaran (RPP), adalah rencana yang menggambarkan prosedur dan pengorganisasian pembelajaran untuk suatu kompetensi dasar yang ditetapkan dalam standar isi dan telah dijabarkan dalam silabus.Rencana pelaksanaan pembelajaran terdiri atas: standar kompetensi,kompetensi dasar,indikator,tujuan pembelajaran,materi pembelajaran,langkah-langkah pembelajaran,alat dan sumber bahan serta penilaian.

Lembar Kerja Siswa (LKS), adalah salah satu bentuk program yang berdasarkan atas tugas yang harus diselesaikan dan fungsi sebagai alat untuk mengalihkan pengetahuan dan keterampilan.LKS memuat identifikasi dan soalsoal yang harus dikerjakan siswa dalam memahami materi pembelajaran yang diberikan untuk mengembangkan dan membangun pengalamannya.

Latihan terbimbing,adalah instruksi bertingkat seperti tangga yang tujuannya memberikan bantuan keterampilan kepada anak agar nantinya bisa menggunakan keterampilan tersebut secara mandiri.

Latihan lanjutan,adalah latihan -latihan untuk pengembangan pengetahuan siswa secara lanjut yang berisikan soal-soal lanjutan yang sesuai dengan materi yang telah diajarkan.

Instrument pengumpul data pada penelitian ini adalah sebagai berikut: Lembar pengamatan aktivitas belajar IPA siswa. Aktivitas belajar IPA siswa kelas V SD Negeri 08 Pinang Sebatang Timur yang diamati dengan menggunakan lembar pengamatan dan penelitian ini antara lain : siswa siap dalam menerima pembelajaran. siswa mendengarkan penjelasan guru. siswa mengerjakan LKS,menjawab,dan presentasi. siswa memperbaiki jawaban yang salah dengan bimbingan guru. siswa mengerjakan latihan lanjutan

Aktivitas guru yang diamati dengan menggunakan lembar pengamatan antara lain : Menyampaikan tujuan pembelajaran dan mempersiapkan siswa. Mendemonstrasikan pengetahuan atau keterampilan sesuai dengan materi yang diajarkan. Membimbing pelatihan siswa. Mengecek pemahaman dan memberikan 
umpan balik. Memberikan kesempatan untuk pelatihan lanjutan dan pemindahan ilmu.

Teknik pengumpul data dilakukan dengan cara : Mengumpulkan nilai hasil belajar siswa selama 2 siklus yang terangkum dalam ulangan harian 1 pada siklus I dan ulangan harian 2 pada siklus II. Ini dilakukan dengan cara memberikan siswa lembar soal ulangan harian 1 dan lembar soal ulangan harian II yang dikerjakan masingmasing siswa.kemudian dinilai oleh guru dan ditentukan nilai yang diperoleh siswa berdasarkan indikator soal yang dibuat. Peneliti mengamati aktivitas siswa dalam proses pembelajaran dan mengisi lembar aktivitas siswa setiap kali proses pembelajaran berlangsung. Peneliti mengamati aktivitas guru dalam menerapkan model pembelajaran dan mengisi lembar pengamatan aktivitas guru yang telah disiapkan sebelumnya.

Data yang telah diperoleh dari hasil penelitian baik itu berupa nilai hasil belajar siswa,hasil lembar pengamatan aktivitas siswa dan lembar pengamatan aktivitas guru kemudian dianalisis.Teknik analisis data yang digunakan adalah analisis statistik deskriptif dan analisis statistik inferensial. Teknik Analisis Data Lembar Pengamatan Siswa dan Guru. Hal ini dilakukan dengan cara analisis statistik deskriptif,ini bertujuan untuk mendeskripsikan aktivitas yang dilakukan siswa selama proses pembelajaran berlangsung dan aktivitas yang dilakukan guru selama menggunakan model pembelajaran langsung dalam proses pembelajaran dengan materi gaya magnet dalam pemecahan masalah dikelas V.analisis ini dilakukan untuk melihat kesesuaian antara perencanaan dengan pelaksanaan tindakan. Pelaksanaan dikatakan sesuai jika semua aktivitas pada tahap pembelajaran langsung ini dapat berjalan sesuai dengan indikator yang telah ditentukan.

Data hasil belajar siswa yang telah dikumpulkan dianalisis dengan cara menskor hasil belajar yang diperoleh dibandingkan dengan nilai hasil ulangan sebelum tindakan dan KKM yang ditetapkan sekolah yaitu nilai 65 .

Data yang dianalisis tersebut adalah data hasil ulangan harian pada setiap indikatornya dengan menggunakan cara presentase.Presentase yang dicari adalah presentase ketuntasan secara individu yaitu siswa mampu memperoleh nilai sama atau diatas KKM sebesar 65 dan secara klasikal ditentukan dengan melihat jumlah siswa yang telah mampu mencapai KKM atau lebih dan membandingkannya dengan skor awal sebelum terjadi tindakan.Skor dasar diperoleh dari skor hasil belajar IPA siswa pada materi sebelumnya.kemudian data juga dianalis secara kualitatif dan kuantitatif.

\section{HASIL PENELITIAN}

Pada tahap ini, peneliti mempersiapkan instrument penelitian yang terdiri dari perangkat pembelajaran yaitu silabus (Lampiran A), Rencana Pelaksanan Pembelajaran (Lampiran B),Lembar Kerja Siswa (Lampiran C), yang disusun untuk enam kali pertemuan dengan menggunakan model pembelajaran demonstrasi.

Instrument pengumpul data adalah lembar pengamatan aktivitas siswa dan aktivitas guru untuk setiap kali pertemuan dan seperangkat tes hasil belajar IPA yang terdiri dari kisi-kisi penulisan soal ulangan harian I dan II,naskah soal ulangan harian Idan II serta alternatif jawaban ulangan harian I dan II.

Pada tahap ini kelas yang mengikuti pembelajaran dengan metode demonstrasi yaitu kelas V SD Negeri 08 Pinang Sebatang Timur yang disebut tindakan.untuk mengetahui ketercapaian kompetensi siswa sebelum tindakan,peneliti menggunakan nilai skor dasar yang diambil dari hasil ulangan harian siswa pada pokok bahasan gaya magnet.Skor ini akan dijadikan tolak ukur peningkatan hasil belajar siswa setelah tindakan.

Pelaksanaan tindakan pada penelitian ini terdiri dari delapan kali pertemuan dengan enam buah RPP dan dua kali ulangan harian.Penelitian ini dilaksanakan sebanyak dua siklus.Siklus pertama dilaksanakan tiga kali pertemuan/tatap muka yang berpedoman pada RPP (RPP-I,RPPII,dan RPP-III), tiga buah lembar Kerja Siswa dan tiga buah lembar latihan lanjutan.Pada pertemuan keempat diadakan ulangan harian I.

Siklus kedua dimulai pada pertemuan kelima sampai pertemuan kedelapan yang juga berpedoman pada tiga RPP (RPP-IV,RPP-V, dan 
RPP-VI), tiga buah Lembar Kerja Siswa dan tiga buah lembar latihan lanjutan siswa.Pada pertemuan kedelapan diadakan ulangan harian II.

Untuk siklus pertama dilakukan sebanyak tiga kali pertemuan dengan satu kali tes (ulangan harian I). Pada pertemuan ini kegiatan pembelajaran membahas tentang Mengelompokkan benda-benda yang bersifat magnetis dan yang tidak magnetis Pertemuan ini diawali dengan menyebutkan tujuan pembelajaran yang ingin dicapai setelah pembelajaran (indikator).Selanjutnya peneliti memberikan apersepsi dan motivasi kepada siswa bahwa keterampilan dalam materi ini perlu diajarkan guna mendapatkan konsep-konsep dari pembelajaran IPA (Tahap 1).

Pada kegiatan inti,peneliti mengawali pembelajaran dengan memberikan penjelasan kepada siswa tentang mengelompokan bendabenda yang bersifat magnetis dan tidak magnetis,peneliti mendemontrasikan pengetahuan/keterampilan tahap demi tahap mengenai materi pelajaran mengelompokan benda-benda yang bersifat magnetis dan tidak magnetis.Dimulai dengan mengelompokan benda bersifat magnetis dengan membuat beberapa contoh benda-benda yang bersifat magnetis,setelah itu dilanjutkan dengan pengelompokan benda-benda tidak magnetis (Tahap 2).

Untuk mengetahui pemahaman siswa, peneliti memberikan bimbingan pelatihan awal dengan membagikan LKS pada setiap siswa dalam kelas. Peneliti mengarahkan siswa agar mengerjakan latihan awal, memberikan petunjuk dalam mengerjakan LKS. Pada bagian ini sebagian mengerjakan sesuai dengan arahan, sementara sebagian siswa yang lainnya ada yang bermain-main. Peneliti tidak menemukan kesungguhan siswa dalam mengerjakan latihan,siswa selalu bertanya kepada peneliti tanpa mau berusaha terlebih dahulu.

Peneliti berkeliling untuk memantau dan memberikan bimbingan kepada siswa yang belum memahami cara menyelesaikan soal yang ada di LKS, sambil mengecek pemahamam siswa dengan cara menanyakan bagian-bagian dari materi pelajaran yang tidak dimengerti dan selanjutnya peneliti bimbingan siswa menyelesaikan soal yang telah diberikan (Tahap $3)$.

Setelah menyelesaikan soal dalam LKS, peneliti memberikan beberapa pertanyaan secara lisan kepada siswa untuk mengetahui pemahaman siswa terhadap materi yang dipelajari, sebagian siswa menjawab dengan benar meskipun masih ada siswa yang menjawab kurang tepat bahkan ada yang tidak menjawab pertanyaan yang diajukan. Kemudian peneliti memberikan pujian kepada siswa yang bertanya dan mampu menjawab pertanyaan yang diberikan peneliti sebagai umpan balik dari semua yang telah mereka pelajari (Tahap 4).

Dalam kegiatan selanjutnya peneliti mempersiapkan kesempatan melakukan pelatihan lanjutan, dengan perhatian khusus pada perencanaan situasi yang lebih kompleks dalam kehidupan sehari-hari. Peneliti memberikan latihan lanjutan dan menyuruh siswa mengerjakan soal tersebut secara individu (Tahap 5). Peneliti memberikan penilaian langsung bagi siswa yang telah selesai mengerjakan latihan lanjutan. Sebelum pembelajaran diakhir, peneliti menugaskan siswa untuk membaca materi selanjutnya yaitu mengelompokan benda-benda yang tidak magnetis.

Pelaksanaan pembelajaran pada pertemuan pertama belum sesuai dengan apa yang diharapkan karena terdapat beberapa kekurangan diantaranya memotivasi yang diberikan guru masih kurang seperti yang tercantum dalam lembar pengamatan pertama, untuk aktivitas siswa pada saat awal mengerjakan soal pada LKS masih banyak siswa yang salah dalam menjawab soal, hal ini dikarenakan siswa ada yang bermain saja dan ada hanya mengharapkan jawaban dari temannya. Untuk mengatasi kekurangan pada pertemuan pertama, peneliti akan melakukan perbaikan seperti bimbingan siswa lebih baik lagi, memberikan motivasi dan memberikan arahan kepada siswa yang hanya bermain saja.

Berdasarkan hsil penelitian yang ditemukan di lapangan maka selanjutnya akan dikemukakan pembahasan dari hasil penelitian. Pada awal pertemuan masih banyak siswa yang belum terbiasa dengan langkah-langkah pembelajaran langsung, misalnya pada pengerjaan soal-soal LKS secara individu siswa banyak berkerja sama dengan teman dekatnya, siswa hanya mencotek hasil temannya, ada siswa yang tidak mengerti mengerjakan soal-soal yang diberikan, siswa kurang percaya diri untuk bertanya, punya rasa takut dan malu bertanya sehingga siswa belum maksimal dalam menerima pelajaran yang menerapkan model pembelajaran demontrasi. 
Pada umumnya kesalahan yang dilakukan siswa dalam mengerjakan soal-soal LKS adalah kurangnya ketelitian siswa dalam memahami sosal-soal tersebut sehingga jawaban yang diberikan tidak sesuai dengan apa yang diinginkan, ada sebagian siswa yang ketelitian siswa yang sifatnya hanya menunggu pekerjaan temannya sehingga mereka tidak mau berusaha mencari jawaban sendiri. Pada ulangan harian 1 kesalahan yang diberikan oleh siswa yang mendapat nilai dibawah KKM dikarenakan mereka kurang teliti mengerjakan soal-soal dan tidak mengulang kembali mencari jawaban yang benar-benar betul. Siswa tersebut ceroboh dalam menyelesaikan ulangan yang diberikan, sedangkan pada ulangan harian II 2 orang siswa yang mendapat nilai di bawah KKM dikarenakan siswa yang bersangkutan memang kurang dalam segi ingatan, walaupun sudah banyak usaha yang diberikan peneliti seperti membimbing siswa tersebut secara individu dan memberikan tambahan jam belajar, namun perubahan yang terjadi dalam dirinya sangat sedikit sekali.

Pada lembar pengamatan peneliti menemukan hampir disetiap pertemuan yang terjadi terus saja terjadi peningkatan aktivitas, baik itu aktivitas yang dilakukan guru maupun aktivitas yang dilakukan siswa. Sehingga peneliti tidak melihat kelemahan-kelemahan dalam proses pembelajaran yang menggunakan metode pembelajaran demonstrasi ini. Intinya metode pembelajaran demontrasi dapat dengan mudah diterapkan pada pembelajaran IPA dengan materi gaya magnet di kelas V SDN 08 Pinang Sebatang Timur Kecamatan Tualang.

\section{KESIMPULAN DAN SARAN}

Berdasarkan hasil penelitian diperoleh kesimpulan bahwa penerapan metode demonstrasi dapat meningkatkan hasil belajar siswa pada mata pelajaran IPA kelas V SD Negeri 08 Pinang Sebatang Timur semester genap tahun 2014/2015.

Dapat dijadikan sebagai salah satu alternatif memperbaiki kualitas proses pembelajaran untuk meningkatkan hasil belajar IPA di kelas V SDN 08 Pinang Sebatang Timur semester genap tahun pelajaran 2014/2015.
Peningkatan aktivitas guru yang dimaksud disini adalah cara guru dalam memberikan pelajaran semakin hari semakin meningkat, dapat menumbuhkan semangat siswa untuk lebih aktif mendengarkan penjelasan guru. Selain itu peningkatan pada aktivitas siswa terjadi seperti siswa sudah banyak yang mau bertanya tentang pelajaran yang tidak mereka mengerti, siswa aktif melakukan kegiatan pembelajaran dengan cermat dan tidak punya rasa ragu-ragu dan malu untuk bertanya. Siswa dapat mengerjakan soalsoal latihan yang diberikan oleh guru dengan mudah dan menjawab dengan benar.

Dari uraian diatas dalam penelitian ini peneliti menemukan beberapa keterbatasan pelaksanaan seperti : Peneliti tidak meminta tanggapan atau saran dari pengamatan. Pengamat dalam peneliti ini hanya satu guru saja.

Secara umum dari analisis tindakan jumlah siswa yang mencapai KKM meningkat setelah dilakukan tindakan. Hasil analisis yang diperoleh pada penelitian ini dengan penerapan metode pembelajaran demonstrasi menunjukkan bahwa jumlah siswa mencapai KKM setelah tindakan yaitu pada ulangan harian 1 dan ulangan harian II lebih tinggi dibandingkan dengan jumlah siswa yang mencapai KKM pada skor dasar $43,6 \%$, ulangan harian $187,2 \%$, ulangan harian II 97,4\%, dengan demikian hasil analisis tindakan ini mendukung hipotesis tindakan yaitu penerapan model pembelajaran demonstrasi dapat meningkatkan hasil belajar siswa kelas V SDN 08 Pinang Sebatang Timur semester genap tahun pelajaran 2014 /2015.

Guru bidang studi IPA khususnya yang mengajar pada kelas $\mathrm{V}$ sekolah dasar hendaknya membiasakan siswa mengembangkan pengetahuanya sehingga siswa memiliki pengetahuan awal terutama dalam memahami konsep pembelajaran dengan baik secara efektif,khusus pada materi gaya magnet.

Kepada peneliti yang berminat menindaklanjuti penelitian ini diharapkan untuk lebih mengembangkan motode pembelajaran demonstrasi. 


\section{DAFTAR PUSTAKA}

Adrian. (2004). Metode Mengajar Berdasarkan Tipologi belajar Siswa. Makalah disampaikan pada diskusi mahasiswa pasca sarjana UHAMKA. Diambil dari http://mtsnslawi.wordpress.com/2011/0 4/06/metode-pembelajaran-eksperimen/

Depdiknas., (2006), kurikulum tingkat Satuan Pendidikan Sekolah Dasar, Jakarta : Departemen Pendidikan Nasional.

Neviyani

(2005)

http://komangwidarmika.blogspot.co.i $\mathrm{d} / 2012 / 12 /$ metode-eksperimen. $\mathrm{html} ? \mathrm{~m}=1$

Winaputra., (1992), Materi Dan Pembelajaran IPA SD, Jakarta : Universitas Terbuka.

Winarno:

http://setiawantopan.wordpress.com/20

12/02/22/metode-penelitian/

Zaini.dkk.(2008).Srategi Pembelajaran

Aktif.Yogyakarta:Pustaka Insan Madani 